\title{
Privatization of Child Welfare Services in the U.S.A. Current Policy in Historical Context
}

\author{
REBECCA L. HEGAR
}

\begin{abstract}
This article analyses historical trends in privatization of child welfare services in the United States, including children's homes, foster family care, and adoption. It also considers how professionalization and deprofessionalization of child welfare services have varied with shifts in the dominant auspices for the provision of social services.
\end{abstract}

\section{Introduction: Organization and Method}

How best to deliver social services is a question that nations tend to resolve in different ways at various times in their histories. Strikingly obvious examples of such shifts occur when economic and political systems undergo drastic changes, such as between pre-war and post-war Germany, or Czechoslovakia under communism and

Rebecca L. Hegar is Professor of Social Work at the University of Texas at Arlington. She is the author of numerous articles and chapters and of two books in the fields of child welfare and family policy. She teaches in the areas of social administration and U.S. and comparative social policy. the post-Communist Czech Republic. Such major upheavals understandably bring about large shifts in the distribution of responsibility for social services among the state or public sector, the voluntary or non-profit sector, and the corporate or forprofit sector of the economy.

All countries confront the question of how to strike the balance among the public, voluntary, and corporate sectors, and, even without major political upheaval, their answers tend to change over time in response to shifts in political philosophy, economic trends, international influences, and other factors. Because of its early colonial history, as well as subsequent transAtlantic exchanges of ideas about social 
services, the U.S.A. has been influenced strongly by English patterns of meeting human needs through a mixed system of public and voluntary agencies and programs (Hegar 2003). Even the moves toward privatization in the Thatcher (1979-1990) and Reagan (1980-1988) administrations can be viewed in the context of incremental shifts that historically have characterized the public/private economic balance.

This article explores the U.S. history of entrusting private citizens and organizations to use public resources and authority to provide child welfare services. It begins with an overview of theoretical approaches to privatization and continues with discussion of child welfare services in several eras of history. U.S. history often is divided into the periods used in this discussion. The colonial period is usually dated from English settlement at the beginning of the 1600s until near the end of the 1700s. Although the 1800s frequently are separated into the pre and post Civil War eras, these are combined here in the interests of brevity. The period of 1900 to about 1930 is often called the Progressive Era, which coincides with the growth of responsibility of the state and federal governments for social programs. During the period of 1930 to 1960 the public sector role in child welfare was at its height, and between 1960 and about 1985 public/private partnerships grew. Since 1980, accelerated privatization in the form of managed care has occured, and ideological approaches (e.g. "faith-based initiativesi) have been proposed.

Historical research is challenging because source materials can be difficult to obtain and assess. In places, standard texts are cited for some historical background (e.g. Jansson 2001, Trattner 1999). Grace Abbott's (1938) compendium of original policy documents, The Child and the State, is the source of several of the statutes and reports cited, particularly some $19^{\text {th }}$ and early $20^{\text {th }}$ century material. Other seminal historical works also were consulted (Folks 1902, Brown 1938, Tierney 1959). Journal articles cited were located through searches of databases (e.g. Social Work Abstracts, PAIS) using search terms including "privatization", "purchase of services", or "contracting out", and »social services» or "child welfare». The approach to policy analysis used here is derived from the author's experience teaching and presenting about social policy (e.g. Hegar 2000, 2002), as well as from the policy theory cited.

The article concludes with a value-based policy analysis focused on contracting for child welfare services, a system in which public funds are transferred to voluntary, and increasingly to corporate, service providers that in turn deliver social services, such as foster care of children. When contracting out the provision of services, the state seeks to retain very significant control over the nature and quality of the services provided. In this way, it is not directly comparable to the principle of subsidiarity that characterizes delegation of social services to major voluntary agencies in some other societies, such as Germany (Sachße 1988).

\section{Theoretical Approaches to Privatization}

Contracting by the state with private 
groups for delivery of social services is one option in the larger debate over privatization of the public sector that first dominated policy discourse under the Reagan (1980-1988) and G. H. Bush (19881992) administrations. Some analysts might place public/private contracting outside the mainstream of that debate, while others include it. Among those who include "contracting out services delivery to private firms through a competitive bidding process", are Motenko and colleagues (1995, p. 456). One analysis that appears to exclude it concludes that "privatization takes on one of two forms that, for the sake of convenience, may be identified as the 'voluntary welfare state' and the 'neo-industrial welfare state» (Gilbert 1986, p.253). In this view, the voluntary welfare state is non-public, involving

mutual aid under voluntary initiatives in what may be thought of as the private sector of the social market. This view holds that it is both possible and desirable for family, friends and local voluntary organizations to assume a greater share or responsibility for dependent members of the community. (Gilbert, 1986, p. 254)

The second form of privatization that Gilbert (1986) discusses, the neo-industrial welfare state, refers to social and other services delivered through the workplace, using a combination of funds from government, employers, and users. This model flourished in the United States before the Great Depression (Gilbert 1986), and it is similar to social welfare as it has evolved in Japan (Gould 1993). It should not be con- fused with what Stoesz (1986) calls "corporate welfare», or the control by for-profit corporations of growing sectors of the human services market, including nursing homes, hospitals, health care, child care, and home health services. However, in their critiques of the neo-industrial welfare state and the corporate welfare state, both Gilbert (1986) and Stoesz (1986) identify a similar shortcoming: under each model most of the benefits accrue to those who are part of the labor force. Neither model appears to offer a realistic alternative to public social services for those who historically have been most dependent on them: the poor, the unemployed, and children whose parents are socially or economically marginalized.

Other social work analysts offer additional ways of defining and conceptualizing privatization. Lohmann advanced the view in 1987 that government might limit its involvement in such fields as mental health, residential and home-based care, and child placement to two functions: provision of "venture capital" and regulation of service delivery. Like the models discussed above, "The primary concern here is the non-poor client population whose service-related problems are not a direct result of income problems» (Lohmann 1987, p. 8), and Lohmann proposes a continued government role in income maintenance. Rosenman's (1989) discussion of social welfare privatization in Australia comes closer to the theme of this article by proposing separate consideration of two trends: private financing and private provision of social services. Private provision includes services delivered by non-profit and for- 
profit organizations, and, when coupled with public funding, includes contracting out and purchase-of-service agreements. This is the same emphasis that Gibelman and Demone 1983 bring to their discussion of privatization: "Purchase of service is one sub-heading of a larger spectrum of arrangements pertaining to the transmission of public funds to private bodies" (ibid p. 22). Contracting services out to the private sector falls within Kamerman's 1983 "public agent model" in which the state retains control through setting standards and conditions of funding.

\section{English Antecedents(1300- 1615) and the U.S. Colonial Period(1615-1789)}

English antecedents. The English Poor Laws were a series of statutes that spelled out public responsibility for the indigent. Children were one of three classes of dependent individuals addressed in the Elizabethan Poor Law of 1601 (Jansson 1997). By that time, the mechanisms for public relief of the poor included direct aid, indenture and apprenticeship, transportation to colonies, and poorhouses and workhouses. Many of these houses were run by religious or other private groups or individuals within the parishes that had responsibility for administering the Poor Law. After the Protestant Reformation, relief work and its institutions often were closely tied to the Anglican Church and clergy.

The Poor Law in the American colonies. The Poor Law of 1601 had been adopted quite recently when English colonization of America began, and, from the early colonial period, poor dependent individuals of all ages were maintained, or boarded, in private homes at public expense. Abbott (1938) reports that "dependent families were frequently auctioned off to the lowest bidders sometimes with a provision in the contract that the children were to have the privilege of going to school in the winter (p. 4). From colonial records in Maryland, Guest (1989) reports that such private boarding was frequently profitable for the predominately upper class households that undertook it. Guest also notes that in the jurisdictions he studied the majority of the poor were black slaves ineligible for public relief, including boarder relief.

Later in the colonial period and in larger settlements, poor houses were established for group care of dependent adults and children. Efforts to separate children from confinement with adults in English poorhouses and workhouses had begun under the Poor Laws as a feature of the Act of 1834 (House 1949, p. xii). In America, a few orphanages were established under religious auspices during the colonial period, for example at the Ursuline Convent in French New Orleans in 1727 and by Reverend Whitefield in Georgia in 1738, however they are not reported to have received public funds (Abbott 1938, Trattner 1999). Along with the few orphanages, the Poor Law solutions of poorhouses and workhouses remained in effect until a new paradigm for child placement, part of the "institutional ideal " of the 19th century (Trattner 1999), spurred the establishment of many separate institutions for children (Hegar 1999). 


\section{Public Support of Private Agencies in the 1800s: The Era of Institutions}

Orphanages replace poorhouses. In the United States, the 1800s brought the enactment of separate statutes and the founding of numerous specialized child-caring institutions, many of them under private auspices. Only after a network of children's placements was developed could states prohibit poorhouse placements, as New York and Massachusetts did in 1875 and 1879, respectively (Abbott 1938, p. 42-3, 71-2). Most of the new orphanages were founded either by religious bodies or by groups of citizens who formed corporations for the purpose (e.g. An Act for the Benefit of the Orphan Asylum Society, 1811).

Subsidies by special appropriation, by fixed amount annually, or by set fee per resident were common vehicles for state support of private institutions serving public purposes. For example, prior to 1870, California provided state aid to private orphans' asylums in all three ways (Pope 1932). The Constitution of California of 1879, while prohibiting state payments to "any institution not under the exclusive management and control of the State as a State institution", never-the-less authorized payments to private institutions caring for orphans or abandoned children, provided that payments were uniform, proportionate to the number of children, and equally available to public institutions.

Controversy over public aid to religious institutions. In 1879 Illinois passed legislation enabling any group of citizens (with a majority of women) to incorporate "not for pecuniary profit « to establish an industrial school for girls and receive a set per capita fee from county funds (Abbott 1938, p. $80)$. Beginning in the 1880 s, serious controversy arose in Illinois over payments to sectarian (religious) institutions, resulting in at least three appellate court challenges of their constitutionality, which ultimately was upheld (Abbott 1938, p. 85-104).

New York became even more committed to state aid to religiously affiliated institutions and agencies when it mandated in 1875 that each dependent child be committed "to an orphan asylum, charitable or other reformatory institution that is governed or controlled by officers or persons of the same religious faith as the parents of such child, so far as practicable». (Laws of the State of New York, 1875). The 1875 statute, passed in reaction to concern that Catholic and Jewish children were being placed in predominately Protestant areas by the New York Children's Aid Society and other groups (Cook 1995), left a troubling legacy of religious and racial separatism that is discussed further later in this article (e.g. see Bernstein 2001).

\section{Public Support of Private Agencies in the Progressive Era (1900-1930)}

The shift to foster family care. By 1900 experts were advocating family placements in preference to institutional care for children (Folks 1902, Smith 1995), and in many jurisdictions private child placing agencies had joined private institutions in receiving public funds. Homer Folks (1902) was 
something of a child welfare prophet for his perspective on the future of contracting for care of children through private agencies:

...shall our state administrations be intrusted (sic) with the management of a system for the care and training of destitute children, or is it wiser to turn that branch of public service over to private charitable corporations, leaving to public officials the functions of paying the bills, and of exercising such supervision over the workings of the plan as may be possible? ...Which it shall be, only the twentieth century can tell. (p. 240)

The matter, however, remained unresolved during the twentieth century, and most jurisdictions developed a mixed system of state and voluntary resources for child placement.

The beginnings of a federal role. In general, public services grew during the period from 1900 through 1930, with some jurisdictions continuing to rely heavily on contracting with voluntary providers. The U.S. Children's Bureau, established in 1912 as the first permanent U.S. federal agency to deal with social welfare matters, had a major role in the growth of public-sector child welfare services. According to Rosenthal (2000), when the Social Security Act of 1935 was drafted and debated, the Bureau advocated for U.S. federal funds to be made available as grants-in-aid for states to fund public child welfare services. Influential voluntary agencies, such as religious child welfare programs, lobbied against funding public agencies, and the compromise that resulted limited public funding to child welfare in rural areas, where competition with established voluntary agencies would be much less.

Racial segregation in services. One issue that surfaces in any review of U.S. child welfare services during the early 1900s is continued racial separatism. As AfricanAmerican migration away from the southern states grew, racial segregation in social services became entrenched in many parts of the U.S. Stehno observes that "By the turn of the twentieth century, the color line had been drawn in children's services in Chicago. This [racial] segregation was the product of the organization of children's services under private auspices in Illinois, and it was also a product of the growing racial hostility in the city" (Stehno 1988, p. 486).

Within the racially and religiously divided network of private children's services, organizations to serve AfricanAmerican children also were founded, in Chicago as elsewhere. However, Stehno (1988) reports that these organizations struggled for resources and could not meet the needs of the growing urban black community. Her research chronicles the history of a separate private foster care agency for black children, which merged with a new public child welfare department when F.D. Roosevelt (1932-1948) was in office. The requirement that the new department serve only families eligible for public financial relief provided access for black children but massured a two-class system of child welfare services: a public agency for the poor and the black and private agencies for the white and the more privileged" (Stehno 1988, p. 497). 


\section{Professionalization of Child Welfare in the Progressive Era}

In the U.S., as in several European countries, professional education for social work began in the last decade of the 1800s with the establishment of educational programs in New York, Chicago, and a few other cities (Kendal 2000, Leighninger 2000). The trend toward professionally prepared workers in child welfare services was furthered by standards promulgated by the U.S. Children's Bureau, the Child Welfare League of America (CWLA), founded in 1920, and by the American Association of Social Workers (AASW), established in 1921. For example, the CWLA published its first standards for the field in 1925, and it long specified professional education in social work as the basic requirement for child welfare roles such as adoption work (CWLA 1978). The AASW was one of seven social work organizations that merged in 1955 to form The National Association of Social Workers. Of the seven original groups, the AASW was most concerned with public sector policy and services (Goldstein \& Beebe 1995), and during the 1920s and 1930s, it consistently raised its educational and practice standards for membership (Brown 1938).

It was not until the 1930s that enough trained social workers were available to staff most of the public and voluntary child welfare programs in the U.S., and by 1935 it was possible for the Social Security Act to require social work education for child welfare staff. Professional social work education, usually at the Masters (MSW) level, remained a standard requirement for many child welfare positions until the trend of deprofessionalization began in the 1970s. More recent issues in professionalization are discussed later in this article.

\section{Public/Private Balance During and After the New Deal (1930-1960)}

The beginning of public child welfare. The first third of the twentieth century was characterized by the continuation of nineteenth century patterns of state support to private children's agencies, but this situation shifted after the mid-1930s. Three factors were primarily involved in the realignment of the public and private sectors. One was the continued shift from institutional to foster home placement of children; the second was the effect of the Great Depression on voluntary organizations, and the last was federal policy under the New Deal administration of F.D. Roosevelt (1932-1948).

The shift from institutional to foster home placement. The 1930s were the time when for the first time more children resided in foster homes than in children's institutions (Jones 1993). This trend tended to strengthen the public sector, because foster care services could be delivered without major capital outlay for buildings, which frequently was possible only with private support (Leahy 1937, p. 111). Although public sector child welfare agencies were strengthened by changing patterns of child placement, some states did continue to place a large proportion of children with private non-profit organizations, many of which made the transition during this period from 
providing institutional care to supervising foster homes and arranging adoptions.

The role of economic depression. The second force that contributed to the growth of public child welfare after 1930 was the Great Depression. Private non-profit agencies sometimes suffered precipitous drops both in the value of their endowments and in annual receipts from philanthropic giving, due to the stock market crash and the declining fortunes of both major patrons and small donors. They also suffered a loss of public funds. Abramovitz (1986) writes that "public subsidies to private agencies, primarily voluntary agencies, continued until the economy collapsed in the 1930s" (p.257). At the same time, economic crisis produced increased need for services that the private sector was simply unable to meet. Gibelman and Demone (1983) conclude of this period that extensive social

...problems of the 1930s made government the only service delivery body capable of mounting and financing the massive programs needed. As a result, the clarity of roles between the two sectors began to erode, with government supplanting services formerly delivered under private auspices.

The role of political ideology. The third factor in the shift from contracting out to direct provision of public sector services was federal policy under F.D. Roosevelt's administration (1932-1948). Homer Folks had predicted in 1902 that services under state auspices would eventually come to dominate the service system, and for the thirty years between about 1934 and 1964 that was truer than at any other time. What changed was the influx of federal money into relief and services during the 1930s, coupled with a federal prohibition against contracting services out to private groups. The force behind that policy was Harry Hopkins, the social worker who headed key federal financial relief programs and was a close advisor of F.D. Roosevelt. Hopkins mandated that public relief funds be administered solely by public agencies (Leahy 1937). Also, the provisions in the 1935 Social Security Act for rural child welfare services helped build a system of public agencies that covered the whole country.

Despite the influx of federal money and mandates into state welfare departments, a significant proportion of child welfare services, particularly substitute care, continued to be contracted out to private agencies. Foster and group care were the areas of child welfare services with which the private sector had the greatest experience and longest history, and they were not supported by federal funding until the 1960s. Werner (1961) reports that in 1957 all but four states made use of services provided by non-profit child welfare agencies. In a few states, the proportion of state-paid foster care delivered by private agencies exceeded 50 percent. Private agencies provided most adoption services without public financial support.

\section{The Era of Partnership in Children's Services (1960 to 1980)}

Purchase of services in foster care. The Services Amendments of 1962 to the Social 
Security Act first made federal monies available to pay for substitute care of children who had been eligible for financial aid in their own homes, and the Amendments explicitly permitted contracting with private agencies to provide foster care. As the number of children in foster placements rose throughout the 1960s due to a variety of causes, it is not surprising that most states continued their patterns of purchasing some foster family and group care. Beginning in 1965 Medicaid extended federal funds to pay for health care of children in federally-funded foster care, including many placements in psychiatric facilities and residential treatment centers, which were more likely to be provided by forprofit organizations in the private sector.

Effects of purchase of services on the disadvantaged and racial minorities. One concern about the expansion of federal social welfare expenditures during the 1960s to mid-1970s is the extent to which this new spending benefited non-poor individuals, in addition to those in poverty. Gilbert (1986) cites Brookings Institution figures showing that from 1973 to 1976 , federal government funding not restricted to the poor increased from 46.5 to 54 percent of total expenditures. Much of this spending was distributed to the states under programs that allowed purchase of services from non-public providers, for example day care for children under Title XX of the Social Security Act, adopted in 1974 (U.S. Code).

The pattern of purchased private services for the more advantaged and public sector services for the poor is reminiscent of pre-1930s inequities in child welfare funding. In the U.S., issues of poverty are inextricably linked to race, and Stehno (1992) cites census data from 1970 showing that black children, for example, made up 21.5 percent of those in public foster care and 13.2 percent of those in private agency homes.

In 1973 in New York City, a class action lawsuit began in which the Children's Rights Project of the American Civil Liberties Union sued the public child welfare agency on behalf of "those New York City children who are black, and who are Protestant, of other non-Catholic or Jewish faiths, or are of no religion, and are in need of child-care services outside of their home» (Wilder v. Bernstein 1980). Two major lawsuits challenged what where presumably unintended consequences of New York City's pattern of relying for substitute care services on contracts with a network of primarily sectarian, non-profit, and highly autonomous agencies (Wilder $v$. Sugarman 1974). That pattern was seen as working to the disadvantage of groups of children for whom fewer placements, or placements of lower quality, had been established, primarily African-Americans of certain or no religious backgrounds.

Advocacy of behalf of the children in the Wilder lawsuits went on for more than fifteen years and generated considerable political heat (Gibelman \& Demone 1983, Bernstein 2001), resulting finally in an agreement to change the process by which children were matched with the agencies that would place them and supervise their care. The decision in this court case finally resolved consequence of the 1875 Act mandating same-religion placements for children in care. 
Purchase of services from the for-profit sector. By the late 1970s, child welfare services purchased from the private sector had reached levels not seen since before the expansion of public services during the 1930s. For example in 1977 private providers under contract with public child welfare agencies nationwide supplied 68 percent of residential treatment, 50 percent of institutional care, and 48 percent of care in group homes (Shyne \& Schroeder 1978). In a departure from the patterns of earlier decades, a little more than half of this care was purchased from the for-profit sector. In addition, almost one-third of day care and day treatment purchased for children in the child welfare system came from forprofit firms (Shyne \& Schroeder 1978).

By 1980, federal funding of social services (not just child welfare services), accounted for more than half of the financial support of many private agencies (Salamon \& Abramson 1985). Recall, however, that late in the nineteenth century New York City orphanages were similarly dependent on public funds. O'Neill concludes that "private welfare agencies at the end of the nineteenth century received well over half of their operating revenue from government" (O'Neill 1989, p. 18). The changes of the 1970s contrast more sharply with the thirty preceding years than with the longer history of private provision and public funding.

\section{The New Conservative Era: Approaches to Privatization After 1980}

Privatization during the Reagan and G.H.
Bush administrations. When Reagan took office in 1980, the non-profit and proprietary sectors long had been involved in the provision of publicly funded child welfare services. Changes during the Reagan (19801988) and G.H. Bush (1988-1992) administrations worked primarily to change the balance between the non-profit and proprietary parts of the private sector. Between 1980 and 1984, Federal funds to the voluntary sector generally (including other fields in addition to social services, but excluding health care) are estimated to have decreased by $\$ 4.5$ billion in constant dollars (Salamon 1984). Changes in federal tax policy to limit deductibility of charitable contributions after 1986 made it clear that the privatization revolution involved an assault on the voluntary sector. Abramovitz (1986, p. 259) concluded that "the final step in the privatization of the welfare state, logically speaking, would be to replace public and nonprofit services with private profit-making alternativesu.

Privatization under the Clinton administration. Transfer of child welfare roles from the public and voluntary sectors to the proprietary market continued to occur under the Democratic Clinton administration (1992-2000). Passage of the Personal Responsibility and Work Opportunity Reconciliation Act of 1996, giving much greater control over child welfare expenditures to the states, brought a new wave of contracting out of services, often to for-profit firms. The Act grants specific permission for federal foster care funds to be paid by states to for-profit children's institutions and agencies (Kamerman \& Kahn 1997). By 1996 "managed care", the term that origi-

Rebecca L. Hegar: Privatization of Child Welfare Services in the USA. 
nated in the health care field, had come to child welfare services.

As in health care, managed child welfare often emphases service delivery by large, private organizations which promise efficiency and cost savings. A guide for child welfare agencies entering the managed care environment defines managed care systems as involving

(1) arrangements for the delivery of services, (2) review of the quality and appropriateness of the services provided, and (3) reimbursement of providers who deliver services. These activities are tied to the two major goals of managed care: (1) reducing the overall costs of service delivery, and (2) ensuring the quality of services that are delivered (Emenhiser et al. 1995, p. x).

Under managed care, public sector agencies retain responsibility for monitoring and reimbursing the private organizations that undertake to deliver services.

States are entering the managed care arena at very different rates. Kansas, for example, received wide publicity as the first state substantially to privatize its foster care and adoption services (Petr and Johnson 1999, McDonald et al. 2000). In early 1997 it completed three phases of contracting out most of its child welfare services. The agencies that assumed broad responsibility for the state's family preservation, child placement, and adoption services are long-established, voluntary agencies. Some other states also have experimented with privatization.

In Texas, the shrinking of the public sector's role in child welfare was already well under way by 1990, when Kamerman and Kahn observed that public child welfare services had narrowed in focus and that any future services to meet the broader needs of families and children "would probably be by other departments or systems, if not by the voluntary sector" (Kamerman \& Kahn 1990, p. 42). In the late 1990s, Texas experimented with contracting out services to foster children in a large region of the state (Texas 1997). Although this experiment ended rather quickly, Texas may well revisit privatization, as is currently being proposed (Strayhorn 2004). Other states are likely to follow suit.

Issues of professionalization in a privatized environment. The rise of privatized approaches to child welfare services has been accompanied by shifts in their professional status. During the 1970s and 1980s public child welfare agencies had experienced widespread deprofessionalization, or the elimination of requirements that staff hold professional qualifications. This occurred despite the fact that national professional organizations consistently have supported a professionally educated child welfare work force. One example is this policy statement adopted in 1987 by the National Association of Social Workers (NASW):

An undergraduate or graduate social work degree should be required for the delivery and administration of social services in public child welfare to ensure that workers have the necessary skills, knowledge, and values to provide high-quality services. (NASW 2000, p. 259)

Such policy statements have had little force, 
and only recently is there a trend in some states, such as Maryland, toward a re-professionalization of public child welfare.

According to membership data of the National Association of Social Workers, whose 150,000 members represent about one-fourth of U.S. social workers, the proportion of social workers primarily employed in the public sector stands at a historic low of 34 percent (Gibelman 1997). Only 8 percent of NASW members are employed primarily in child welfare and family services in any sector, while a majority work in health, mental health, or substance abuse (NASW 2003). At least 27 percent of NASW members now are employed primarily in the corporate, for-profit sector, while 39 percent work in agencies in the voluntary sector (Gibelman \& Schervish 1997).

While this might suggest that the private sector employs highly qualified staff, that is not always the case. Although there still are highly professional voluntary agencies and public programs, the trend since 1980 has been toward the employment of non-social workers or those with lesser credentials in both public and private child welfare services. Many contracting agencies employ non-social workers to deliver most services, a trend fueled by low pay scales and benefits in some private child welfare agencies in many parts of the country. This recent U.S. experience with respect to professionalization may be instructive as European countries grapple with similar trends toward privatization (e.g. Van der Lann 1998).

Privatization under the G.W. Bush administration. Under the 1st administration of G.W. Bush (2000-2004), an additional approach to privatization of social services has been introduced. Early in his tenure as President, G.W. Bush created the Office of Faith-Based and Community Initiatives with the objective of channeling public funds to religious congregations and similar organizations to provide social services (Wallis 2003). This approach differs from the historical U.S. pattern of contracting for services in that established voluntary agencies are responsible to the community through the terms of their incorporation, which include accountability to Boards of Directors with broad-based memberships. They may not discriminate based on race, religion, age, disability, or sex in providing federally funded services.

Other faith-based organizations, such as religious congregations, are much less accountable to the larger community and have more latitude in decisions concerning whom to hire and serve. They also rarely employ professionally educated social workers, so that delegation of service provision to such organizations also implies further de-professionalization of social work roles. However, Bush's Faith-Based Initiative has received little support to date from Congress, so it remains a proposal. Because of the reelection in 2004 of President G.W. Bush and strong Republican majorities in the U.S. Senate and House of Representatives, delivery of social services in overtly religious settings can be expected to gain ground.

\section{Contracting Out as Social Policy: A Value-Based Analysis}

Values underpinning social policy. Purchase of services from the private sector is an 
example of social policy means rather than ends. Debates over how to deliver social services can lose sight of the desired ends of social policy, and they sometimes fail to make explicit the values that underpin selection of particular strategies from the range of available alternatives. There is a long tradition in the British and U.S. policy literature of value-based analysis (e.g. Tawney 1931, Dewey 1939, Titmuss 1950, Rawls 1958, 1971, Rein 1970, Dunn 1981, Hardy 1981, Chambers 2000, Hegar 2000, 2002, Rawls \& Kelly 2001). The discussion in this section draws from Moroney's (1981) value-analytic approach to policy analysis, which in turn builds on the work of Titmuss (1950, 1971) and Rein (1970).

Somewhat before "values" became a conservative political catchword in the U.S., Moroney (1981, p. 85) explicated their role in social policy formulation and analysis in this way:

...values permeate the entire policy process. Values influence the selection of the specific policy issue and how it will be defined. Values are the basis for setting policy goals and objectives, for selecting criteria, for comparing policy options to achieve these goals and objectives, and for evaluating policies once they are implemented.

Moroney concludes that social policy may be rooted in any of three "first principles»: liberty, equality, and fraternity. Which of these, then, are the values that underlie the recent debates over contracting out, managed care, and privatization in the social services?

Values that underlie privatization. Although much of the political discourse has tended to elevate means of service delivery to the level of policy goals, the conservative, pro-privatization forces have actually been quite clear about their basic values: individual responsibility; autonomous traditional families; voluntary patterns of association, and individual and corporate freedom of action. If one applies these values to the problem of child welfare services, the choices are self-evident: less state intervention in families; choice among multiple providers of services; private responsibility for payment; reliance on competition, and profit in the marketplace. Of the three over-arching principles or values that Moroney identifies, these goals are concerned primarily with advancing liberty. Moroney (1981, p. 94) concludes that, „if we were to select liberty as the primary value, the analyst would probably generate criteria with an emphasis on choice, multiple modalities of services and benefits, a weighting toward the private sector, and a limited role for government». Specific decisions to cut public agency budgets, to promote decentralization and contracting, and to allow profit-making, follow naturally from the desire to maximize the value of liberty.

Values as the basis for public services. Compared with conservatives, recent U.S. advocates of the public role in social services have been less successful at articulating the core values underpinning their positions. In U.S. political dialogue, advocates of the public sector frequently are designated as "liberal", a different use of the term than is common in Europe. U.S. liberals often try to maximize the second among Moroney's core value criteria, equal- 
ity (treating similarly situated individuals alike) and its corollary, equity (providing compensatory benefits in the interest of fairness). Both policies that benefit everyone and those that redistribute resources flow from this value criterion. In child welfare services, equality is served when all children and their families have good access to similar services. Provision and payment by the state is a logical means to that end.

Moroney himself prefers that family and children's services maximize a third value, fraternity, which frequently is invoked by both liberals and conservatives. Fraternity, literally brotherhood, underpins solutions that emphasize "the existence of common need and risk, and the necessity for shared responsibility" (ibid, p. 94). Policies that advance the value of fraternity reinforce group membership and interdependence, demonstrate altruism, and cultivate shared experiences. Fraternity extends the obligations of brotherhood beyond the family, and Moroney uses the word "community" as a synonym. Although present-day conservatives often talk about the importance of community initiatives, group self-help, local control, and philanthropic responsibility for addressing social problems, policy changes during the 1980s actually undermined this value.

The value contributions of the voluntary sector. Beginning perhaps with German sociologist Max Weber (1910), theorists have considered what role voluntary associations have in mediating between individuals and a bureaucratic society (e.g. Berger \& Neuhaus 1977, O’Neill 1989). For immigrant Americans of the 1800s, the network of ethnic and religious agencies that provided child welfare services were important mediating structures. Sectarian agencies still serve that function, as do many other types of not-for-profit service organizations. The diminished role since 1980 of voluntary organizations in providing government-purchased social services, as discussed above, is an example of a decline of community-mindedness and fraternalism. Gilbert (1986, p. 375) observes that commercialization in social welfare has "the potential to undermine the existing charitable and communal ideas of the social market".

The challenge of racial inclusiveness under privatization. This article places some emphasis on assessing the adequacy of services to African-Americans in the child welfare systems of different eras. To summarize, African-Americans were excluded from Poor Law solutions in many jurisdictions and unserved by most private asylums of the 1800s. A dual system of public and private agencies in this century has usually guaranteed the under-representation of black children in the private sector and their concentration in public programs avoided by those who could exercise greater choice.

It is difficult to see how privatization in the form of managed care, which depends on payments by users or third parties, will be inclusive of the historically disadvantaged, generally, and of African-Americans in particular. Managed care approaches to delivering child welfare services may prohibit service providers from rejecting specific clients referred by state agencies (e.g. Texas 1997). However, there are no guarantees that managed care or faith-based 
providers will meet the needs of children by aggressively recruiting foster and adoptive homes in ethnic minority communities or by serving gay or lesbian families. Access to services for new immigrants and other U.S. minorities may prove as challenging in a highly privatized child welfare system as access for African-Americans historically has done.

Conclusions of the value analysis. Moroney (1981) emphasizes that the three principal values he identifies can not all be achieved simultaneously, so that trade-offs among them are necessary. Although he chooses fraternity as a primary value, Moroney's own analysis of child care services includes a generous measure of equality, including universal provision of services. Although no one advocates universal provision of services like child protection and child placement, universal access, equitable treatment, and high quality services for those in need of protection or placement are important goals. In the past, these standards have been advanced by a strong public role in regulating and funding social services, whether those were provided within the public or voluntary sectors.

A public policy designed to balance the values of fraternity and equality can allow for contracting out of social services to voluntary agencies. It can not accommodate a social service marketplace with significantly expanded participation by faithbased organizations that fail to subscribe to goals of equal access and inclusiveness or by the for-profit, corporate sector. Generating profits for share holders is a necessary goal in a capitalist economy, but it is fundamentally incompatible both with equality of access and treatment and with fraternal interest in assisting others. This is being amply demonstrated in managed health care, which has come to be dominated by the corporate sector in the U.S. To replicate the same policies in child welfare and family services would be an error of extraordinary proportions.

\section{References}

Abbott, G. (1938) The Child and the State, vol. 2, Chicago: University of Chicago Press.

Abramovitz, M. (1986) "The privatization of the welfare state: A review», Social Work, 31, 257264.

An Act for the Benefit of the Orphan Asylum Society, Laws of the State of New York, Vol. 6, Chap. 86 (1810-1812), reprinted in Abbott, G. (1938) The Child and the State, vol. 2, Chicago: University of Chicago Press.

Berger, P.L. \& Neuhaus, R. J. (1977) To Empower People: The Role of Mediating Structures in
Public Policy, Washington, American Enterprise Institute for Public Policy Research.

Bernstein, N. (2001) The Lost Children of Wilder: The Epic Struggle to Change Foster Care, New York: Vintage Books.

Brown, E.L. (1938) Social Work as a Profession, 3rd edition. New York: Russell Sage Foundation.

Chambers, D.E. (2000) Social Policy and Social Programs: A Method for the Practical Public Policy Analyst, 3rd edition. Boston: Allyn and Bacon.

Child Welfare League of America, Inc. (CWLA) 
(1978) In P. Romanofsky (ed.), The Greenwood encyclopedia of American institutions: Social service organizations, vol 1, pp. 224-230. Westport: Connecticut, Greenwood Press.

Child Welfare League of America (1996) CWLA Standards of Excellence for the Management and Governance of Child Welfare Organizations. Washington: Author.

Constitution of the State of California, Art. 4, Sec. 22 (1879), reprinted in Abbott, G., The Child and the State, vol. 2. Chicago: University of Chicago Press, 1939.

Cook, J.F. (1995) "A history of placing out: The orphan trains", Child Welfare, 74, 181-197.

Dewey, J. (1939) Theory of Valuation. Chicago: University of Chicago Press.

Dunn, W.N., ed. (1981) "Symposium on Social Values and Public Policy». Policy Studies Journal (special Issue), 2, 519-636.

Emenhiser D., Barker R. and DeWoody M. (1995) Managed Care: An Agency Guide to Surviving the Thriving. Washington: Child Welfare League.

Folks, H. (1902) The Care of Destitute, Neglected, and Delinquent Children. New York: Macmillan.

Gibelman, M. and Demone, H. (1983) »The politics of privatization: Industrial social work and private enterprise", Urban and Social Change Review, 16, 21-26.

Gibelman, M. and Schervish, P.H. (1997) Who We Are: A Second Look. Washington: DC, National Association of Social Workers.

Gilbert, N. (1986) „The welfare state set adrift», Social Work, 31, 457-63.

Goldstein, S.R. \& Beebe, L. (1995) „National Association of Social Workers", in $19^{\text {th }}$ Encyclopedia of Social Work, vol 2, pp. 1747-1764. Washington: DC, NASW Press.

Gould, A. (1993) Capitalist Welfare Systems: A Comparison of Japan, Britain, and Sweden. New York: Longman.

Guest, G. (1989) »The boarding of the dependent poor in colonial America", Social Service Review, 63, 92-112.

Hardy, J. (1981) Values in Social Policy: Nine Contradictions. London: Routledge \& Kegan Paul.
Hegar, R. (1999) „Kinship foster care: The new child placement paradigm». In Hegar, R. and Scannapieco, M. (eds), Kinship foster Care: Policy, Practice, and Research. New York: Oxford.

Hegar, R. (2000) »Toward equitable societies: The contributions of comparative social policy analysis", paper presented at the Joint Conference of the International Federation of Social Workers and the International Association of Schools of Social Work, Montreal, Canada, 29 July- 1 August 2000.

Hegar, R. (2002) "Assessing models for teaching comparative social policy", paper presented at the Policy Conference for Social Work Education and Practice, Charleston, SC, USA, 15-18 June 2002.

Hegar, R. (2003) „Two models for the role of social work in society: Contrasts involving Europe and the USA", paper presented at the International Federation of Social Workers European Seminar 2003: Social Work in a Future Europe, Copenhagen, Denmark, 26-29 May 2003.

House, H. (1949) "Introduction", in Dickens, C., Oliver Twist. Oxford: Oxford University Press. Jansson, B. (2001) The Reluctant Welfare State: American Social Welfare Policies- Past, Present, and Future, $4^{\text {th }}$ edition. Pacific Grove, CA: Brooks Cole.

Jones, M.B. (1993) "The decline of the American orphanage, 1941-1980", Social Service Review, 67, 463.

Kamerman, S. (1983) "The new mixed economy of welfare: Public and private», Social Work, 28 , 5-10.

Kamerman, S. \& Kahn, A.J., (eds.) (1997) Child Welfare in the Context of Welfare 'Reform', New York: Columbia University School of Social Work.

Kendall, K.A. (2000) Social Work Education: Its Origins in Europe, Alexandria, VA, Council on Social Work Education.

Laws of the State of New York. (1875) Chap. 173, sec. 2, reprinted in Abbott, G. (1938), The Child and the State, vol. 2. Chicago: University of Chicago Press.

Leahy, M. (1937) Brief Summary of Provisions for

Rebecca L. Hegar: Privatization of Child Welfare Services in the USA. 
the Care of Department and Neglected Children in the State of North Dakota, Public Welfare Board of North Dakota, reprinted in Abbott, G, (1938), The Child and the State, vol. 2. Chicago: University of Chicago Press.

Leighninger, L. (2000) Creating a New Profession: The Beginnings of Social Work Education in the United States. Alexandria, VA: Council on Social Work Education.

Lohmann, R. (1987) „Private social services in a welfare society", Journal of Independent Social Work, 2, 7-19.

McDonald T.V., Berry M., Paterson E., and Scott D. (2000) "Adoption trends in Kansas: Managing outcomes or managing care?" Children and Youth Services Review, 22, 161-174.

Moroney, R. (1981) „Policy analysis within a valuetheoretical framework", in Haskins, R. and Gallagher, J.J. (eds.) Models for Analysis of Social Policy. Norwood, NJ: Ablex Publishing.

Motenko A.K., Allen E.A., Angelos P., Block L., DeVito J., Duffy A., Holton L., Lambert C.P., Ryan J., Schraft D., and Swindell A. (1995) „Privatization and cutbacks: Social work and client impressions of service delivery in Massachusetts", Social Work, 40, 457-63.

National Association of Social Workers. (2000) "Public child welfare", in Social Work Speaks: National Association of Social Workers Policy Statements: 2000-2002, pp.259-260. Washington, DC: NASW Press.

National Association of Social Workers. (2003) Retrieved April 15, 2003 from www.nasw.org.

O'Neill, M. (1989) The Third America: The Emergence of the Non-profit Sector in the United States. San Francisco: Jossey-Bass Pub.

Petr, C. \& Johnson, I.C. (1999) »Privatization of foster care in Kansas: A cautionary tale», Social Work, 44, 263-267.

Pope, M.M. (1932) Third Biennial Report of the Department of Social Welfare of the State of California, July 1. 1930 to June 30, 1932, reprinted in Abbott, G., (1938), The Child and the State, vol. 2. Chicago: University of Chicago Press.

Rawls, J. (1958) „Justice and fairnessu. The Philosophical Review 67, 164-194

Rawls, J. (1971) A Theory of Justice. Cambridge
Mass: Harvard University Press.

Rawls, J. \& Kelly, E (2001) Justice as Fairness - A

Restatement. Cambridge: Harward University Press

Rein, M. (1970) Social Policy: Issues of Choice and Change. New York: Random House.

Rosenman, L. (1989) „Privatization of social welfare services and social work practice: An overview of the issues", Australian Social Work, 42, 5-10.

Rosenthal, M.G. (2000), „Public or private children's services? Privatization in retrospect", Social Service Review, 74, 281-305.

Sachße, C. (1988) „Subsidiarität", in Kreft, D. and Mielenz, I., (eds.), Wörterbuch Sociale Arbeit, revised edition. Weinheim: Beltz.

Salamon, L.M. (1984) "The results are coming in", Foundation News, July/August, 16-23.

Salamon, L.M. \& Abramson, A. (1985) The Federal Budget and the Nonprofit Sector. Washington: The Urban Institute.

Shyne, A. and Schroeder, A. (1978) The National Study of Social Services to Children and Their Families. Washington: United States Children's Bureau.

Smith, E.P. (1995). "Bring back the orphanages? What policymakers of today can learn from the past", Child Welfare, 74, 459-480.

Stehno, S. (1988) „Public responsibility for dependent Black children: The advocacy of Edith Abbott and Sophonisba Brackinridge", Social Services Review, 62, 485-503.

Stehno, S. (1992) "Differential treatment of minority children in service systems", Social Work, 27, 39-45.

Stoesz, D. (1986) "Corporate welfare: The third stage of welfare in the United States", Social Work, 31, 245-249.

Strayhorn, C.K. (2004) Forgotten Children: A Special Report of the Texas Foster Care System. Austin, Texas: State Comptroller's Office. Retrieved April 10, 2004 from www.us.texas. gov.

Tawney, R.H. (1931, reprinted 1964) Equality. London: George Allen and Unwin.

Texas Department of Protective and Regulatory Services (1997) Competitive Procurement 
System for Contract Care. Austin, Texas: TDPRS.

Tierney, B. (1959) Medieval Poor Law: A Sketch of Canonical Theory and Its Application in England. Berkeley: University of California Press.

Titmuss, R. (1950) Problems of Social Policy. London: Her Majesty's Stationary Office.

Titmuss, R. (1971, reissued 1997) The Gift Relationship: From Human Blood to Social Policy, revised edition, edited in Oakley, A. \& Ashton, J.(eds.) New York: New Press.

Trattner, W.A. (1999) From Poor Law to Welfare State: A History of Social Welfare in America, 6 th Edition. New York: Free Press.

U.S. Code, Section 1397-1397F, Subchapter XX, Chapter 7, Title 42.
Van der Lann, G. (1998) »The professional role of social work in a market environment", European Journal of Social Work, 1 (1), 31-40.

Wallis, J. (2003) "Putting God back in politics», New York Times, 28 December, sec. 4, p. 9.

Weber, M. (1910, reprinted 1972) „Max Weber's proposal for the sociological study of voluntary associations", Journal of Voluntary Action Research, 1, 20-23.

Werner, R.M. (1961) Public Financing of Voluntary Agency Foster Care. New York: Child Welfare League of America.

Wilder v. Bernstein, 499 Federal Supplement 980, 994 (S.D.N.Y. 1980).

Wilder v. Sugarman, 395 Federal Supplement $1013(1974)$.

\section{Summary}

\section{Privatization of child welfare services in the USA Current policy in historical context}

In recent years, the shift from public to voluntary and corporate sector responsibility for social services has been characterized as "privatization". Several ways of conceptualizing privatization are reviewed and applied to the US context, with occasional international comparisons. For example, for decades the provision of services through the voluntary sector in the US followed Kamerman's "public agent model" (1983), in which the state retains control both through regulations or standards and through conditions attached to funding. Under recent conservative presidential administrations, there has been more focus on a form of privatization which
Stoesz (1986) calls "corporate welfare", or the control by corporations of growing sectors of the human services market, including nursing homes, hospitals, health care, child care, and home health services. This article analyses historical trends in privatization of child welfare services, including children's homes, foster family care, and adoption. It also considers how professionalization and deprofessionalization of child welfare services have varied with shifts in the dominant auspices for the provision of social services. In conclusion, the article applies to the issue of privatization a valuebased approach to policy analysis (Moroney 1981). 